\title{
HUBUNGAN ANTARA KOHESIVITAS KELOMPOK DAN EFIKASI DIRI DENGAN KEMALASAN SOSIAL PADA ANGGOTA ORGANISASI
}

\author{
Nurcholifah Fajrin dan Abdurrohim \\ Fakultas Psikologi Universitas Islam Sultan Agung Semarang
}

Email: abdurrohim@unissula.ac.id

\begin{abstract}
Abstrak
Penelitian ini bertujuan untuk mengetahui hubungan antara kohesivitas kelompok dan efikasi diri dengan kemalasan sosial pada anggota organisasi. Penelitian ini menggunakan metode kuantitatif dengan analisa yang dilakukan pada 140 anggota organisasi Badan Eksekutif Mahasiswa dari beberapa fakultas yang berada di Unissula Semarang. Pengambilan data dalam penelitian ini menggunakan tiga skala, yaitu skala kemalasan sosial, skala kohesivitas kelompok dan skala efikasi diri. Skala kemalasan sosial berjumlah 27 aitem dengan rentang daya beda $0,300-0,698$ dan koefisien reliabilitas $=0,919$. Skala kohesivitas kelompok berjumlah 24 aitem dengan rentang daya beda $0,328-0,748$ dan koefisien reliabilitas $=0,917$. Skala efikasi diri berjumlah 25 aitem dengan rentang daya beda 0,340 - 0,665 dan koefisien reliabilitas $=0,916$. Terdapat dua teknik analisis data yang digunakan, yaitu analisis regresi ganda untuk menguji hipotesis pertama serta korelasi parsial untuk menguji hipotesis kedua dan ketiga. Hasil uji hipotesis pertama diterima, yaitu ada hubungan antara kohesivitas kelompok dan efikasi diri dengan kemalasan sosial, dimana korelasi $R=0,608$ dan $F_{\text {hitung }}=40,158$ dengan taraf signifikansi $p=0,000(p<0,01)$. Hasil tersebut menunjukkan adanya hubungan yang sangat signifikan. Hasil uji hipotesis yang kedua dapat diterima, yaitu ada hubungan negatif antara kohesivitas kelompok dengan kemalasan sosial, dimana perolehan korelasi $\quad r_{y \times 1-x 2}=-0,318$ dengan taraf signifikansi $p=$ $0,000(p<0,01)$ yang menunjukkan ada hubungan negatif sangat signifikan. Hasil uji hipotesis yang ketiga dapat diterima, yaitu ada hubungan negatif antara efikasi diri dengan kemalasan sosial, dimana perolehan korelasi $r_{y \times 1-x 2}=-0,197$ dengan taraf signifikansi $p=0,020(p<0,05)$ yang menunjukkan ada hubungan negatif signifikan.
\end{abstract}

Kata kunci: kemalasan sosial, kohesivitas kelompok, efikasi diri

\section{THE RELATIONSHIP BETWEEN GROUP COHESIVENESS AND SELF-EFFICACY WITH SOCIAL LOAFING ON THE ORGANIZATION}

\begin{abstract}
This research aimed to determine the correlation between group cohesiveness and self-efficacy with social loafing on the organization members. This research used quantitative methods to the analysis conducted on 140 members of the organization BEM of faculties that are in Unissula Semarang. Collecting data in this research using three scales, the scale of social loafing, group cohesiveness scale and the scale of self-efficacy. The social loafing scale consists of 27 items with corrected item-total correlation about 0,300 - 0,698, Cronbach's Alpha 0,919. The group cohesiveness scale consists of 24 items with corrected item-total correlation about 0,328-0,748, Cronbach's Alpha 0,917. The self-efficacy scale consists of 25 items with corrected itemtotal correlation about 0,340-0,665, Cronbach's Alpha 0,916. There are two data analysis techniques are used, the multiple regression analysis to test the first hypothesis and partial correlations to test the hypothesis of the second and third. The first hypothesis can be accepted, that there is a relationship between group cohesiveness and self-efficacy with social loafing, where the correlation $R=0,608$ and $F_{\text {count }}=40,158$ with a significance level of $p=0,000(p<0,01)$. These results indicate a highly significant relationship. The second hypothesis can be accepted, that there is a negative relationship between group cohesiveness with social loafing, where the acquisition of correlation $r_{y \times 1-x 2}=-0,318$ with a significance level of $p=0,000(p<0,01)$, which showed a negative correlation is very significant. The third hypothesis can be accepted, that there is a negative relationship
\end{abstract}


between self-efficacy with social loafing, where the acquisition of correlation $r_{y \times 1-\times 2}=-0,197$ with a significance level of $p=0,020(p<0,05)$, which showed a negative correlation is significant.

Keywords: social loafing, group cohesiveness, self-efficacy

\section{Pendahuluan}

Organisasi dapat didefinisikan sebagai suatu kelompok formal yang terdiri dari dua orang atau lebih untuk mencapai visi dan misi yang sama. Ciri dari organisasi adalah adanya hubungan kewenangan dan level pembagian tenaga kerja (Robbins, 2002). Ciri tersebut berperan terhadap produktifitas organisasi. Organisasi dapat berjalan dengan baik karena adanya kinerja anggota yang produktif. Namun tidak menutup kemungkinan bahwa dalam sebuah organisasi terdapat anggota yang pasif, sehingga kurang mampu menjalankan fungsi-fungsi organisasi dengan baik, kurang adanya keterbukaan dan cenderung membatasi diri dalam berkontribusi (Bungin, 2006).

Anggota dalam sebuah organisasi memiliki peran penting bagi keberhasilan organisasi. Keberhasilan organisasi didapat karena adanya kebersamaan antar sesama anggota organisasi. Meskipun demikian, ada pula beberapa anggota organisasi yang memiliki rasa malu saat berkumpul dan memandang bahwa pendapat yang disampaikan selalu dihiraukan. Hal ini menyebabkan terjadinya kemalasan sosial (Aulia \& Saloom, 2013).

Sarlito (2012) mengemukakan bahwa kemalasan sosial merupakan pengurangan motivasi dan usaha individu ketika berkontribusi dalam sebuah kelompok dibandingkan pada saat bekerja secara individual. Chidambaran (Aulia \& Saloom, 2013) juga membuktikan bahwa kemalasan sosial dapat mengurangi produktifitas dalam organisasi. Selain itu, Bacon (Hall \& Buzwell, 2012) mengemukakan bahwa kemalasan sosial tidak hanya merugikan sebuah organisasi, namun juga dapat merugikan diri individu secara pribadi.

Anggota organisasi yang melakukan kemalasan sosial tidak dibatasi oleh usia dan jenis kelamin. Clark \& Baker (2011) mengemukakan bahwa kemalasan sosial berpeluang terjadi pada laki-laki maupun perempuan dan segala kegiatan yang dilakukan secara berkelompok. Selain itu, hasil penelitian yang dilakukan oleh Aulia \& Saloom (2013), menunjukkan bahwa kemalasan sosial dapat dilakukan dari berbagai kalangan usia.

Kemalasan sosial yang terjadi dalam sebuah organisasi dapat menghilangkan fungsi kerjasama sebagai bentuk kinerja yang efektif dan efisien (Anggraeni \& Alfian, 2015). Faktor-faktor yang mempengaruhi kemalasan sosial dapat ditemukan dari berbagai hal yang didapatkan individu baik dalam mengerjakan tugas kelompok maupun organisasi, seperti yang dikemukakan oleh Anggraeni \& Alfian (2015), yaitu: a)Ukuran kelompok; Ukuran kelompok dapat menentukan seberapa besar individu melakukan kontribusi dan memberikan penilaian. Ketika individu berada dalam kelompok besar maka akan lebih sulit bagi individu untuk berkontribusi dan memandang bahwa usaha yang dilakukan tidak akan mempengaruhi hasil penilaian serta dapat menyebabkan penurunan upaya yang diberikan (Latane, dkk., 1979). b) Budaya (individualistis - kolektivistis); Individu dengan budaya kolektivistis dapat bekerjasama secara kelompok karena merasa memiliki kesamaan karakteristik dan latar belakang, sehingga lebih peduli terhadap pencapaian kelompok. Hal ini berbeda dengan individu yang memiliki budaya individualis, dimana individu lebih mementingkan pencapaian pribadi. (Clark \& Baker, 2011). c) Pembagian tugas; Pembagian tugas dapat menentukan kinerja tim dan kepuasan anggota. Sehingga pembagian tugas dan beban kerja harus dilakukan secara adil supaya individu yang tergabung dalam kelompok atau organisasi tidak merasa malas dan terdiskriminasi 
serta efektifitas kinerja dapat meningkat (Pang, dkk., 2011). d) Kepribadian individu; Kepribadian individu sebagai anggota organisasi antara satu dengan yang lain pasti berbeda dan perbedaan tersebut dapat berpengaruh terhadap kemalasan sosial. Sehingga perbedaan kepribadian harus lebih diperhatikan supaya produktifitas organisasi tetap terjaga (Goo, 2011). e) Kohesivitas; Kohesivitas dapat diartikan sebagai kekompakan kelompok dan sangat berperan terhadap kinerja anggota kelompok. Apabila anggota kelompok tidak saling menyukai satu sama lain, maka kontribusi yang diberikan akan berkurang. Namun ketika anggota kelompok merasa saling memiliki, maka individu akan berkontribusi dengan maksimal (Liden, dkk., 2004). Menurut Erdal, dkk., (2016), beberapa penyebab kemalasan sosial diantaranya adalah individu berbuat malas dan terlihat santai sehingga individu yang lain mengikuti perilaku tersebut. Dengan demikian individu akan memunculkan sikap individualis ketika berada dalam suatu kelompok dan mengurangi kohesivitas dalam organisasi. Liden \& Bennett (2004) mengemukakan bahwa salah satu penyebab kemalasan sosial adalah kohesivitas kelompok yang rendah. Individu yang melakukan kemalasan sosial juga dipengaruhi oleh berbagai aspek yang diungkapkan Fishbein dan Ajzen (Sutanto dan Simanjuntak, 2015), yaitu: 1) Perilaku (behavior); Perilaku khusus yang diperlihatkan secara nyata oleh individu, dimana perilaku khusus tersebut adalah perilaku yang menunjukkan individu kurang berkontribusi dalam kelompok. 2) Sasaran (target); Sasaran yang dituju merupakan objek dari perilaku kemalasan sosial individu, dimana objek perilaku tersebut diperlihatkan oleh rekan antar sesama kelompok dalam mengerjakan tugas atau memberikan kontribusi dalam kelompok. 3) Situasi (situation); Situasi dari keadaan lingkungan setempat dapat menimbulkan perilaku kemalasan sosial, hal ini dapat dilihat melalui perilaku individu ketika mengerjakan tugas atau memberikan kontribusi dalam kelompok. 4) Waktu (time); Waktu merupakan penentu disaat kapan perilaku kemalasan sosial individu akan diperlihatkan, dimana waktu yang dilihat adalah waktu ketika individu mengerjakan tugas atau berkontribusi dalam kelompok.

Kohesivitas kelompok merupakan faktor-faktor yang dimiliki kelompok untuk membuat anggota kelompok tetap berada menjadi bagian dari kelompok (Sarlito \& Meinarno, 2012). Menurut Walgito (Abdillah, 2012) kohesivitas meliputi keterikatan antar anggota kelompok maupun keterikatan anggota pada kelompoknya dan merupakan perhatian anggota kelompok untuk saling menyukai satu sama lain. Apabila kohesivitas kelompok tinggi maka dapat terbentuk sebuah konformitas, meningkatnya komunikasi dalam kelompok dan memiliki rasa kebersamaan (Vaughan dan Hogg dalam Sarlito \& Meinarno, 2012).

Anggraeni \& Alfian (2015) mengemukakan bahwa kohesivitas dapat memberikan pengaruh positif bagi individu dari lingkungan maupun anggota kelompok. Semakin kuat kebersamaan dan ketertarikan antar sesama anggota maupun anggota terhadap kelompok, maka semakin kohesif pula anggota dalam kelompok tersebut. Menurut Aulia \& Saloom (2013) ketika kohesivitas kelompok menurun membutuhkan kesadaran akan kepercayaan diri individu untuk melakukan sesuatu agar lebih maksimal sehingga tidak akan terjadi kemalasan sosial.

Daya tarik antar sesama anggota maupun anggota terhadap kelompok merupakan salah satu faktor yang mempengaruhi kohesivitas kelompok. Menurut Thoha (1998) kohesivitas kelompok dapat dipengaruhi oleh berbagai hal, yaitu sebagai berikut: a) Kesempatan berinteraksi; Sebagai makhluk sosial, interaksi merupakan hal yang penting untuk menjalin sebuah komunikasi dan ketertarikan antar sesama individu. Kesempatan berinteraksi yang diberikan dalam sebuah kelompok atau organisasi dapat menimbulkan kebersamaan dan hubungan timbal balik yang positif. Dalam hal 
ini faktor lingkungan juga berperan dalam menjalin interaksi, dimana individu yang jarang bertemu dan berbicara satu sama lain cenderung dapat menurangi kekompakan dan kurang menjalin kerjasama dengan baik. b) Status; Terdapat dua kecenderungan yang berkaitan dengan status dalam faktor kohesivitas. Pertama, yaitu individu tertarik pada orang lain berdasarkan kesamaan status, dimana individu yang berstatus tinggi lebih senang berinteraksi dengan individu yang berstatus tinggi pula. Kedua, yaitu individu tertarik pada orang lain yang memiliki status lebih tinggi, dimana individu yang berstatus rendah lebih tertarik pada individu yang berstatus tinggi. c)Kesamaan latar belakang; Individu yang memiliki latar belakang yang sama, seperti usia, jenis kelamin, agama, pendidikan, ras, kebangsaan dan status ekonomi, maka cenderung mudah untuk tertarik dan berinteraksi satu sama lain. d) Kesamaan sikap; Kesamaan sikap merupakan bentuk realisasi dari kesamaan latar belakang individu. Dimana individu yang memiliki latar belakang sama, cenderung memiliki kesamaan pengalaman, dan pengalaman yang sama dapat menimbulkan kesamaan sikap. Kohesivitas kelompok terdiri dari empat aspek yang dikemukakan oleh (Carron, dkk., 2002), diantaranya adalah: a) Ketertarikan individu pada tugas kelompok (Individual attractions to the group-task) yang merupakan ketertarikan individu terhadap tujuan kelompok dan kinerja kelompok. Sehingga ketika bekerja dalam kelompok dapat merasa nyaman untuk mencapai tujuan dan keberhasilan kelompok. b) Ketertarikan individu pada kelompok sosial (Individual attractions to the group-social) merupakan perasaan setiap anggota kelompok untuk bersedia menerima kehadiran orang lain atau penerimaan diri terhadap seseorang dan interaksi sosial dengan kelompok. c) Kesatuan kelompok berdasarkan tugas (Group integration-task) yaitu persepsi individu mengenai kedekatan dan ikatan dalam kelompok, dimana anggota kelompok beranggapan bahwa kegiatan yang dilaksanakan kelompok merupakan tujuan yang ingin dicapai. d) Kesatuan kelompok berdasarkan sosial (Group integrationsocial) adalah persepsi individu mengenai kedekatan dan ikatan dalam kelompok sebagai seluruh bagian sosial, dimana individu memandang kelompok sebagai sarana untuk berinteraksi yang mampu menimbulkan rasa nyaman.

Kepercayaan diri individu dalam penelitian ini diartikan sebagai efikasi diri yang merupakan salah satu aspek dari kepribadian. Bandura (1986) memiliki konsep mengenai efikasi diri, yaitu bagaimana individu menginterpretasikan atau memaknai hubungan timbal balik dari lingkungan yang mempengaruhi perilaku dan menentukan keyakinan seseorang dalam bertindak. Efikasi diri berkaitan dengan seberapa besar pengetahuan dan perilaku anggota organisasi yang dipengaruhi oleh lingkungan, serta bagaimana cara menghadapi proses berpikir terhadap informasi-informasi yang diterima. Bandura (Sahertian, 2010) mengemukakan bahwa efikasi diri berkaitan dengan keyakinan seseorang terhadap kemampuan yang dimiliki dalam mengontrol lingkungan. Faktor-faktor yang mempengaruhi efikasi diri secara keseluruhan dikemukakan oleh Albert Bandura. Seperti yang dijelaskan oleh Bandura (Mukhid, 2009) bahwa efikasi diri meliputi empat faktor, yaitu: a) Penguasaan pengalaman yang menetap; Peristiwa masa lalu ketika individu mencapai kesuksesan maupun kegagalan merupakan pengalaman yang dapat melekat dalam diri individu. Pengalaman kesuksesan mampu meningkatkan efikasi diri, sedangkan pengalaman kegagalan dapat melemahkan efikasi diri karena individu mengurangi usahanya untuk bertindak. b) Pengalaman yang dirasakan individu pribadi; Pengalaman yang dirasakan sendiri oleh individu diperoleh melalui behavioral model, dimana individu mengamati kemampuan orang lain dalam menyelesaikan tugas atau persoalan dan menimbulkan keyakinan pada diri individu bahwa dirinya juga dapat menyelesaikan tugas atau persoalan yang sama. c) Bujukan sosial; Bujukan sosial dapat diperoleh dari hubungan 
interaksi antar sesama individu. Individu yang dibujuk secara verbal dapat menumbuhkan semangat dan mendapatkan sugesti dari orang lain bahwa diri individu mampu mengatasi masalah-masalah yang sedang dihadapi. d) Keadaan emosi; Efikasi diri atau keyakinan dalam diri individu mudah ditimbulkan karena perasaan dan suasana hati (mood) daripada situasi atau kondisi. Hal ini dikarenakan suasana hati (mood) dapat mempengaruhi usaha individu dalam bertindak. Aspek-aspek efikasi diri merupakan hal yang penting untuk mendeteksi perilaku seseorang dalam menjalankan kehidupan sehari-hari. Menurut Bandura (Hartawati \& Mariyanti, 2014) efikasi diri terdiri dari tiga aspek, yaitu: a) Tingkat (level); Tingkat (level) berkaitan dengan tingkat kesulitan tugas yang dihadapi. Perbedanaan efikasi diri yang dimiliki individu dapat mempengaruhi persepsi terhadap tingkat kesulitan tugas yang dihadapi, seperti halnya tugas dengan tingkat kesulitan rendah atau sederhana, sedang hingga tinggi atau sulit. b) Keluasan (generality); Keluasan (generality) berkaitan dengan seberapa luas individu memiliki keyakinan akan kemampuan yang dimiliki dalam menyelesaikan berbagai tugas, baik melalui tingkah laku, kognitif maupun afektif. c) Kekuatan (strength); Kekuatan (strength) berkaitan dengan sejauh mana keyakinan yang dimiliki individu. Dalam hal ini, ketahanan dan ketekunan merupakan hal yang dibutuhkan dalam proses menyelesaikan tugas. Individu yang memiliki efikasi diri rendah akan mudah menyerah, sebaliknya individu yang memiliki efikasi diri tinggi akan berusaha dengan maksimal meskipun banyak rintangan yang dihadapi

Legowo, dkk., (2010) menyatakan bahwa efikasi diri dapat menentukan seberapa besar usaha yang diberikan dan seberapa kuat individu bertahan dalam menghadapi pengalaman yang tidak menyenangkan. Selain itu, Moelino (2012) menyatakan bahwa efikasi diri tidak hanya mempengaruhi seberapa besar keyakinan dalam menghadapi tantangan yang dapat dilalui, namun juga dapat menentukan motivasi individu dalam berkontribusi. Efikasi diri juga sangat berperan pada individu yang tergabung dalam organisasi.

Anggota organisasi yang memiliki efikasi diri tinggi, dapat menentukan tujuan dan mengerahkan segala kemampuan untuk mencapai harapan yang dituju, namun ketika dihadapkan dengan kesulitan dan hambatan, anggota tersebut akan berusaha untuk tetap bertahan dan berhasil mencapai tujuan secara maksimal (Lee \& Bobko dalam Sahertian, 2010). Sehingga ketika berkontribusi dapat memberikan usaha yang maksimal tanpa menimbulkan kemalasan sosial.

\section{METODE}

Metode pengumpulan data menggunakan skala psikologi, yaitu skala sikap (likert) yang berupa skala kemalasan sosial (27 aitem), skala kohesivitas kelompok (24 aitem) dan skala efikasi diri (25 aitem). Penelitian ini menggunakan teknik korelasi Product Moment Pearson sebagai teknik uji daya beda aitem dan untuk mengetahui koefisien reliabilitas, menggunakan teknik Alpha Cronbach. Teknik analisis data yang digunakan adalah analisis regresi ganda untuk menguji hipotesis pertama kemudian kolerasi parsial untuk menguji hipotesis kedua dan ketiga. Perhitungan statistik dalam penelitian ini menggunakan bantuan SPSS (Statistical Product and Service Solution) versi 16.

\section{HASIL}

Hasil uji hipotesis pertama menggunakan analisis regresi ganda dengan perolehan korelasi $\mathrm{R}$ sebesar 0,608 dan $F_{\text {hitung }}$ sebesar 40,158 dengan taraf signifikansi $p=0,000(p<0,01)$. Hasil tersebut menunjukkan bahwa kohesivitas kelompok dan efikasi diri memiliki hubungan yang sangat signifikan dengan kemalasan sosial. Berdasarkan hasil perhitungan statistik dalam penelitian ini diperoleh juga 
bahwa R Square sebesar 0,370 yang menunjukkan bahwa sumbangan efektif antara kohesivitas kelompok dan efikasi diri memberikan kontribusi sebesar 37\% terhadap kemalasan sosial.

Uji hipotesis kedua dalam penelitian ini adalah untuk mengetahui apakah terdapat hubungan antara kohesivitas kelompok dengan kemalasan sosial. Hasil perhitungan diperoleh nilai korelasi $r_{\mathrm{yx} 1-}$ $x_{2}=-0,318$ dengan taraf signifikansi $p=0,000(p<0,01)$. Hasil tersebut menunjukkan terdapat hubungan negatif yang sangat signifikan antara kohesivitas kelompok dengan kemalasan sosial. Semakin tinggi kohesivitas kelompok maka semakin rendah terjadinya kemalasan sosial. Sebaliknya, semakin rendah kohesivitas kelompok maka semakin tinggi kemalasan sosial yang terjadi.

Uji hipotesis ketiga dalam penelitian ini untuk menguji apakah terdapat hubungan antara efikasi diri dengan kemalasan sosial. Hasil perhitungan diperoleh nilai korelasi $r_{y \times 1-\times 2}=-0,197$ dengan taraf signifikansi $p=0,02(p<0,05)$. Hasil tersebut menunjukkan korelasi yang lemah namun terdapat hubungan negatif yang signifikan antara efikasi diri dengan kemalasan sosial. Semakin tinggi efikasi diri yang dimiliki individu maka semakin rendah terjadinya kemalasan sosial. Sebaliknya, semakin rendah efikasi diri yang dimiliki individu maka semakin tinggi terjadinya kemalasan sosial.

\section{PEMBAHASAN}

Penelitian ini bertujuan untuk mengetahui apakah terdapat hubungan antara kohesivitas kelompok dan efikasi diri dengan kemalasan sosial pada anggota organisasi. Hasil uji hipotesis pertama pada penelitian ini menunjukkan nilai korelasi $R$ sebesar 0,608 dan $F_{\text {hitung }}$ sebesar 40,158 dengan taraf signifikansi $\quad p=0,000(p<0,01)$. Hasil perhitungan tersebut menunjukkan bahwa terdapat hubungan yang sangat signifikan antara kohesivitas kelompok dan efikasi diri dengan kemalasan sosial pada anggota organisasi.

Kemalasan sosial yang timbul dalam sebuah organisasi, biasanya terjadi pada saat melaksanakan sebuah kegiatan, dimana inividu atau anggota tersebut mengurangi kontribusi dalam kelompok dan menghindari tanggungjawab. Semakin besar anggota memiliki rasa tanggungjawab terhadap rekan organisasi, maka rasa keterlibatan untuk berkontribusi meningkat dan dapat mencapai tujuan kelompok (Tan \& Li, 2008).

Bekerjasama antar sesama anggota dalam sebuah organisasi bukanlah hal yang dapat dihindari, melainkan dengan adanya kerjasama dapat meningkatkan produktifitas dan pencapaian organisasi. Namun, anggota organisasi cenderung merasa malas ketika bekerjasaama dengan anggota yang tidak satu pemikiran. Hal tersebut merupakan dampak negatif dari kemalasan sosial. Brooks dan Ammons (2003) mengatakan bahwa salah satu dampak negatif dari kemalasan sosial adalah berkurangnya kekompakan.

Kekompakan atau kohesivitas dalam sebuah kelompok merupakan suatu hal yang sangat dibutuhkan dalam keberhasilan suatu organisasi. Selain itu, Tan \& Li (2008) mengatakan kohesivitas kelompok juga dapat mempengaruhi perilaku kemalasan sosial. Adanya kohesivitas dalam kelompok dapat memberikan pengaruh positif baik pada organisasi maupun pada anggota organisasi, serta menurunkan permasalahan atau kesenjangan yang muncul dalam organisasi. Dalam beberapa penelitian, kohesivitas kelompok disebabkan karena kelekatan yang terjadi dalam kelompok, sehingga anggota kelompok atau organisasi berkeinginan untuk tetap tinggal di dalam organisasi tersbut (Dwiyanto \& Amalia, 2012).

Organisasi yang mampu menunjukkan kekompakan, tentunya tidak akan terjadi kemalasan sosial dan memiliki anggota yang dapat percaya atau yakin akan pencapaian pada usaha yang telah 
dilakukan. Hal tersebut dinamakan dengan efikasi diri. Efikasi diri merupakan salah satu faktor yang menjembatani interaksi antara faktor perilaku dengan faktor lingkungan dan sebagai penentu keberhasilan performance dalam melaksanakan kegiatan atau pekerjaan (Lodjo, 2013). Dengan adanya efikasi diri yang dimiliki individu dapat membawa perubahan pada lingkungan sosial, karena menurut Snyder dan Lopez (Pihasniwati, dkk., 2014) konsep efikasi diri berpengaruh terhadap hubungan sosial seseorang terhadap orang lain.

Hipotesis kedua dalam penelitian ini yaitu ingin mengetahui apakah terdapat hubungan negatif antara kohesivitas kelompok dengan kemalasan sosial pada anggota organisasi. Hasil perhitungan korelasi parsial menunjukkan nilai korelasi $r_{y \times 1-x 2}=-0,318$ dengan taraf signifikansi $p=0,000(p<0,01)$ yang menandakan bahwa terdapat hubungan negatif yang sangat signifikan antara kohesivitas kelompok dengan kemalasan sosial. Semakin tinggi kohesivitas kelompok maka semakin rendah terjadinya kemalasan sosial. Sebaliknya, semakin rendah kohesivitas kelompok maka semakin tinggi kemalasan sosial yang terjadi pada anggota organisasi.

Kurnia \& Shinta (2015) mengemukakan ketertarikan anggota untuk menjadi bagian dari kelompok dapat memicu hubungan yang harmonis antar sesama anggota organisasi dan mengurangi kemalasan sosial, karena ketertarikan yang timbul dari dalam diri individu, moral yang terdapat dalam kelompok, efektifitas kelompok dan umpan balik dari pemimpin maupun sesama anggota merupakan kunci untuk terbentuknya suatu kohesivitas (Bachroni, 2011).

Purwaningwulan (Kurnia \& Shinta, 2015) mengemukakan bahwa semakin tinggi kohesivitas yang dimiliki kelompok, maka kebersamaan yang terbentuk dalam organisasi semakin kuat dan menurunkan terjadinya kemalasan sosial dalam kelompok atau organisasi. Namun, jika kohesivitas dalam kelompok rendah, maka perselisihan dan kemalasan sosial terhadap kelompok dapat meningkat. Begitu pula dengan yang diungkapkan oleh Qomaria, dkk., (2015).

bahwa semakin anggota memiliki ketertarikan atau keterikatan terhadap kelompok, maka semakin kohesif dan terhindar dari kemalasan sosial.

Hipotesis ketiga dalam penelitian ini yaitu ingin mengetahui apakah terdapat hubungan negatif antara efikasi diri dengan kemalasan sosial. Hasil perhitungan korelasi parsial menunjukkan nilai korelasi $r_{y \times 1-\times 2}=-0,197$ dengan taraf signifikansi $p=0,02(p<0,05)$ yang menandakan bahwa terdapat hubungan negatif yang signifikan antara efikasi diri dengan kemalasan sosial. Semakin tinggi efikasi diri yang dimiliki individu maka semakin rendah terjadinya kemalasan sosial. Sebaliknya, semakin rendah efikasi diri yang dimiliki individu maka semakin tinggi terjadinya kemalasan sosial.

Rustika (2012) mengungkapkan bahwa individu yang memiliki efikasi diri tinggi dapat mengurangi kecemasan dan tidak mengalami harga diri rendah. Hal ini sesuai dengan penelitian McDougall dan Kang (2003) mengenai memory self-efficacy and memory performance in older males yang menghasilkan korelasi negatif antara efikasi diri dengan kecemasan dan harga diri. Berdasarkan penelitian tersebut menandakan bahwa apabila individu memiliki efikasi diri yang tinggi maka mampu mengurangi rasa cemas dan mampu berkontribusi dengan baik dalam sebuah organisasi.

Penelitian yang dilakukan oleh Bandura (Sigiro \& Cahyono, 2005) menyatakan bahwa ketika individu mendapatkan feedback yang negatif dan individu tersebut memiliki efikasi diri yang tinggi, maka akan dapat merespon dengan meningkatkan usaha untuk mengatasi apa yang dihadapi. Sebaliknya, ketika individu memiliki efikasi diri yang rendah, maka cenderung suka merendahkan diri dan membuat kinerja menurun sehingga menyebabkan kemalasan sosial. 
Rigby (Halimah, dkk., 2015) mengemukakan ketika individu atau anggota organisasi memiliki efikasi diri namun terintimidasi oleh anggota lain, maka membuat individu tersebut merasa tidak bersedia melakukan apapun yang menjadikan individu malas untuk berkontribusi. Meskipun individu dari berbagai kalangan pada dasarnya memiliki efikasi diri, namun efikasi diri yang terbentuk berbeda-beda pada setiap individu.

Efikasi diri dapat dikatakan sebagai penentu keberhasilan dalam melaksanakan pekerjaan (Lodjo, 2013). Penelitian yang dilakukan oleh Judge dan Bono (2001) menghasilkan adanya hubungan yang positif antara efikasi diri dengan kinerja. Seharusnya, semakin tinggi efikasi diri yang dimiliki individu maka semakin tinggi pula performansi kerja, mampu mengontrol emosi dan selalu berusaha menghadapi rintangan. Namun, apabila efikasi diri rendah, maka individu tersebut selalu merasa gagal, tidak berarti, takut untuk bertindak dan menimbulkan penuruanan kinerja yang mampu memicu terjadinya kemalasan sosial (Katz-Navon, dkk., 2007).

Hasil analisis data dalam penelitian ini menunjukkan bahwa kemalasan sosial yang terjadi pada anggota organisasi berada pada kategori rendah. Hal ini diketahui berdasarkan mean empirik skor subjek yang berada dalam kategori rendah yaitu 59,0429. Hasil analisis data kohesivitas kelompok dan efikasi diri berada pada kategori tinggi. Hal tersebut berdasarkan pada mean empirik skor subjek yang berada dalam kategori tinggi yaitu 75,7643 dan juga mean empirik skor subjek efikasi diri yang berada dalam kategori tinggi yaitu 76,1500. Kohesivitas kelompok memberikan sumbangan efektif sebesar $23,75 \%$ terhadap kemalasan sosial, sedangkan efikasi diri memberikan sumbangan efektif sebesar $13,25 \%$ terhadap kemalasan sosial. Hal tersebut menunjukkan bahwa kontribusi kohesivitas kelompok lebih besar daripada kontribusi efikasi diri terhadap kemalasan sosial.

\section{KESIMPULAN DAN SARAN}

Hipotesis pertama menghasilkan korelasi $R$ sebesar 0,608 dan $F_{\text {hitung }}$ sebesar 40,158 dengan taraf signifikansi $p=0,000(p<0,01)$. Hsil tersebut menunjukkan bahwa terdapat ubungan yang sangat signifikan antara kohesivitas kelompok dan efikasi diri dengan kemalasan sosial pada anggota organisasi. Pada hipotesis kedua, hasil perolehan korelasi $r_{y \times 1-\times 2}=-0,318$ dengan taraf signifikansi $p=$ $0,000(p<0,01)$ menunjukkan bahwa terdapat hubungan negatif yang sangat signifikan. Semakin tinggi kohesivitas kelompok maka semakin rendah kemalasan sosial yang terjadi pada anggota organisasi. Sebaliknya, semakin rendah kohesivitas kelompok maka semakin tinggi kemalasan sosial yang terjadi.

Hipotesis ketiga menghasilkan korelasi yang lemah, dimana koefisien korelasi $r_{\mathrm{yx} 1-\times 2}=-0,197$ dengan taraf signifikansi $p=0,02(p<0,05)$ yang menunjukkan bahwa terdapat hubungan negatif yang signifikan. Semakin tinggi efikasi diri yang dimiliki individu maka semakin rendah terjadinya kemalasan sosial. Sebaliknya, semakin rendah efikasi diri yang dimiliki individu maka semakin tinggi kemalasan sosial yang terjadi.

Berdasarkan hasil penelitian yang telah dilakukan, peneliti mencoba memberikan beberapa saran, yaitu:

1. Bagi anggota dan organisasi

a. Anggota organisasi diharapkan tidak ragu untuk menyampaikan aspirasi pada saat rapat.

b. Anggota organisasi dapat meningkatkan keyakinan dari dalam diri untuk berusaha dan mencapai kebehasilan. 
c. Meskipun akan ada pergantian kepengurusan, namun harus tetap percaya diri dan membimbing penerus organisasi dengan baik.

d. Saling terbuka dengan sesama anggota organisasi agar dapat menjalin komunikasi, hubungan yang harmonis dan kebersamaan tetap terjaga.

e. Organisasi sebaiknya bersedia menerima masukan dari setiap anggota agar dapat mengetahui kendala atau kekurangan organisasi.

2. Bagi peneliti selanjutnya

a. Peneliti selanjutnya sebaiknya lebih memperhatikan waktu pengambilan data supaya tidak berbenturan dengan pergantian kepengurusan organisasi.

b. Peneliti selanjutnya dapat melakukan penelitian dengan variabel lain yang berpengaruh terhadap kemalasan sosial, seperti ukuran kelompok, pembagian tugas dan budaya organisasi.

\section{Daftar Pustaka}

Abdillah, F. (2012). Hubungan Kohesivitas Kelompok dengan Intensi Turnover Pada Karyawan. Journal of Social and Industrial Psychology, 1(2), 52-58.

Anggraeni, F., \& Alfian, I. N. (2015). Hubungan Kohesivitas dan Social Loafing dalam Pengerjaan Tugas Berkelompok pada Mahasiswa Psikologi Universitas Airlangga. Jurnal Psikologi Kepribadian dan Sosial, 4(2), 81-87.

Aulia, H., \& Saloom, G. (2013, April). Pengaruh Kohesivitas kelompok dan Self Efficacy Terhadap Social Loafing Pada Anggota Organisasi Kedaerahan di Lingkungan UIN Syarif Hidayatullah Jakarta. Journal of Psychology, 18(1), 79-88.

Bachroni, M. (2011). Pelatihan Pembentukan Tim Untuk Meningkatkan Kohesivitas Tim Pada Kopertis $\checkmark$ Yogyakarta. Jurnal Psikologi, 38(1), 40-51.

Bandura, A. (1986). Social Foundations of Thought and Action: a Social Cognitive Theory. New Jersey: Prentice-Hall.

Brehm, S. S., \& Kassin, S. M. (1996). Social Psychology. New Jersey: Houghton Mifflin.

Brooks, A. C., \& Ammons, J. (2003). Free Riding In Group Project and The Affects of Timing, Frequency, and Specificity of Criteria in Peer Assessments. Journal of Education for Business, 78(5), 268-272.

Bungin, B. (2006). Sosiologi Komunikasi. Jakarta: Kencana Prenada Media Group.

Clark, J., \& Baker, T. (2011). "It's Not Fair!" Cultural Attitude to Social Loafing in Ethnically Diverse Groups. Intercultural Communication Studies, 20(1), 124-137.

Dwiyanto, A., \& Amalia, P. A. (2012). Hubungan Antara Kohesivitas Kelompok Dengan Komitmen Organisasi Pada Karyawan. Prosiding Seminar Nasional Psikologi Islami (pp. 270-276). Surakarta: Fakultas Psikologi Universitas Muhammadiyah Surakarta.

Erdal, Emel, Hulya, \& Zekeriya. (2016). The Effects of Organizational Commitment on Social Loafing Behavior at Higher Education Instutions. International Refereed Academic Social Sciences Journal, 96-113.

Halimah, A., Khumas, A., \& Zainuddin, K. (2015). Persepsi Pada Bystander Terhadap Intensitas Bullying Pada Siswa SMP. Jurnal Psikologi, 42(2), 129-140.

Hall, D., \& Buzwell, S. (2012). The Problem of Free-riding in Group Projects: Looking Beyond Social Loafing as Reason for Non-contribution. Journal Permissions, 1(1), 1-13. 
Katz-Navon, T., Naveh, E., \& Stern, Z. (2007). Safety Self-Efficacy and Safety Performance. International Journal of Health Care Quality Assurance, 20(7), 572-584.

Kurnia, T., \& Shinta, A. (2015). Hubungan Antara Kohesivitas Organisasi dengan Aktualisasi Diri Pada Anggota Komunitas Pemuda Gereja. Seminar Psikologi dan kemanusiaan (pp. 396-400). Yogyakarta: Psychology Forum UMM.

Legowo, V. A., Yuwono, S., \& Rustam, A. (2010). Correlation Between Self Efficacy and Perception of Leadership Transformational Style with Job Participation on The Employees. Jurnal Psikohumanika, 3(1), 1-13.

Liden, R. C., Wayne, S. J., Jaworski, R. A., \& Bennett, N. (2004). Social Loafing: A Field Investigation. Journal of Management, 30(2), 285-304.

Lodjo, F. S. (2013). Pengaruh Pelatihan, Pemberdayaan dan Efikasi Diri Terhadap Kepuasan Kerja. Jurnal EMBA, 1(3), 747-755.

McDougall, G. J., \& Kang, J. (2003). Memory Self-Efficacy and Memory Perfoemance in Older Males. International Journal of Men's Health, 2(2), 131-147.

Moelino, L. (2012). Self-Efficacy Pada Seorang Perempuan Mantan Pecandu Napza - Sebuah Studi Kasus. Jurnal IImiah Psikologi Manasa, 1(1), 1-13.

Pihasniwati, Slamet, \& Muslimah, H. L. (2014). Program Pelatihan Motivasi Berprestasi Guna Meningkatkan Efikasi Diri dan Optimisme Pada Mahasiswa Aktivis Organisasi Sebagai Pengurus Organisasi di "Universitas Islam Negeri Sunan Kalijaga" Yogyakarta. Jurnal Psikologi Integratif, 2(2), 72-90.

Qomaria, N., Musadieq, M. A., \& Susilo, H. (2015). Peran Kohesivitas Kelompok Untuk Menciptakan Lingkungan Kerja Yang Kondusif. Jurnal Administrasi Bisnis, 29(1), 77-85.

Robbins, S. P. (2002). Prinsip-prinsip Perilaku Organisasi (5 ed.). (N. Mahanani, Ed., Halida, \& D. Sartika, Trans.) Jakarta: Penerbit Erlangga.

Rustika, I. M. (2012). Efikasi Diri: Tinjauan Teori Albert Bandura. Buletin Psikologi, 20(2), 18-25.

Sahertian, P. (2010). Perilaku Kepemimpinan Berorientasi Hubungan dan Tugas Sebagai Anteseden Komitmen Organisasional, Self Efficacy, dan Organizational Citizenship Behavior (OCB). Jurnal manajemen dan kewirausahaan, 12(2), 156-169.

Sarlito, \& Meinarno, E. (2012). Psikologi sosial. Jakarta: Salemba Humanika.

Sears, D. O., Freedman, J., \& Anne, L. (2009). Psikologi Sosial (5 ed., Vol. 2). (M. Adryanto, Penerj.) Jakarta: Erlangga.

Sigiro, \& Cahyono. (2005). Analisis Perbedaan Tingkat Kepuasan Kerja ditinjau dari Locus of Control, Tipe Kepribadian dan Self-Efficacy. Jurnal Bisnis dan Manajemen, 5(2).

Tan, H. H., \& Li, M. (2008). Organizational Citizenship Behavior and Social Loafing: The Role of Personality, Motives, and Contextual factors. The Journal of Psychology, 142(1), 89-108. 